Article

\title{
How DMO Can Measure the Experiences of a Large Territory
}

\author{
Simona Franzoni * and Michelle Bonera \\ Department of Economics and Management, University of Brescia, Contrada Santa Chiara 50, 25122 Brescia, \\ Italy; michelle.bonera@unibs.it \\ * Correspondence: simona.franzoni@unibs.it
}

Received: 9 December 2018; Accepted: 15 January 2019; Published: 18 January 2019

\begin{abstract}
This paper aims at providing a methodology for analyzing and measuring the experiences offered by a large territory by investigating online conversation on the "things to do" or in other words the experiences by TripAdvisor platform. Opinions and comments are able to influence the choice of the tourist destination and to raise specific expectations, in order to find corrective measures to be taken to preserve or enhance the interest of a tourist destination. By applying the methodology advanced, Destination Management Organization (DMO) can collect useful information in order to make decisions and take action to protect and/or increase the competitiveness of the destination. The empirical observation, thought the methodology described herein, was applied in the Province of Brescia, Italy, a large territory marked by the presence of different destinations and experiences and Bresciatourism-Visit Brescia, the DMO of this territory, was involved.
\end{abstract}

Keywords: DMO; experiences; reviews; TripAdvisor; methodology; descriptive analysis; sentiment analysis; content analysis; Province of Brescia; Italy

\section{Introduction}

Social media has influenced the travelers shopping process [1]: it is a space where users can share experiences, make recommendations and express preferences [2-4]. Regarding tourism, 30\% of travelers start their search on the net without having a destination in mind [5]. According to a study, in 2016, $95 \%$ of tourists read reviews on destinations before booking their vacation and $70 \%$ of travelers read up to 20 reviews in the planning phase, spending on average thirty minutes to read comments from other users [6]. Digital travelers are increasingly connected and need an increasing number of information to perfect the purchase of a tourist product [7].

The specific features of e-word-of-mouth (enhanced volume, dispersion, persistence and observability, anonymity and deception, salience of valence, and community engagement) make it a major source of information [8] also in the tourism field. The digital traveler uses e-word of mouth [9-11], that is to say, any digital communication mode (cell phone, computer, tablet, etc.), and makes his review at any time of the trip [12]. When he/she lives a travel experience, he/she makes his/her own review (whether positive or negative) at any time, not only to inform the group of friends of the visited places, but to provide advice and suggestions to interested travelers to the same experience [13]. In particular, travelers' reviews provide information about tourism products and services (hotels, restaurants, museums, travel companies, etc.) and represent recommendations [14] and describe experiences and activities that can be done in a certain destination [4]. The travel reviewer socializes what excites him/her [15]. The reviews take place mainly when the experience touches the emotional sphere, either positive or negative.

Therefore, tourism reviews are important ex-post evaluation basis of the tourist's customer satisfaction $[16,17]$ with the visit of the destination and a spontaneous and authentic indication without 
excessive intrusion of tour operators. For the destination management organizations (DMO), it is, therefore, necessary to know and analyze the online opinions and conversations [18] referring to not just touristic products and services but also touristic experiences as they are able, on one side, to influence the choice of tourist destination and to create specific experience expectations [19]. On the other hand, a monitoring activity can help the DMO itself detecting and classify the existing and perceived tourism experiences of a destination and, therefore, evaluate the experiential potentiality of the same.

As literature [20-22] shows that the demand for experience is the major trend in the global tourist industry. The purpose of this paper is to provide a methodology for investigating, analysing and measuring the experiences offered by a tourist destination and to monitor the experiential needs of the future tourists, as online conversations will influence their curiosity and this is a trigger of their propensity to learn, do, experiment, explore and experience [23]. The results of the analysis done using our proposed methodology can be useful to define the future destination promotion activity and to identify corrective actions, aimed at maintaining, increasing or implementing the experiences required. The DMO, willing to contribute to improve the attractiveness of a tourist destination, needs to focus on experiences rather than just services in order to increase the competitiveness of the destination [24-29]. Therefore, the proposed methodology aims at specifically dedicating to the touristic experiences, but also provides a procedure that can study all the possible experiences offered by a territory and not just one at a time.

The paper first analyses the literature on tourism "experience" [30-32] and measurement systems [33] of the destination competitiveness (Section 2). Next, the advanced methodology is described in detail (Section 3) and applied to tourism destinations of a large territory (Province of Brescia, Italy). Section 4 presents the results. The findings are combined and used in order to generalize the proposed methodology and its capacity to help DMO to appraise the experiential offerings of a tourism destination. Finally, Section 5 draws some implications and conclusions.

\section{Literature Review}

Today, tourists want to be totally immersed in the destination they visit. In order to achieve lasting advantage, it is important to create experiences only relevant to that particular place and to create a link in the mind of the tourist between the activity and the location.

At this point, it is essential to focus on the concept of "experience" [34-36] understood as "something strange" that happens to individuals and as such, is not directly accessible or viewable except by those who live it in person. Experiencing is not the only contingent on what the destination provides but also on how the mind perceives the activity it is engaged in and as it interacts with its environment. Experiences are created internally and each person creates his/her own experience based on past experiences, education, values, attitudes and beliefs [30].

Tourist experiences are generated through visiting, learning and enjoying activities in a location and situation away from home [31,32,37].

There have been numerous attempts to define the tourist experience in the literature. The tourist experience is considered one of the tourists' subjective mental states [38], a sensation that is a result of the interaction with the destination [39], the result of the visit [37], the creation of value that occurs when tourism production and consumption meet, a subjective assessment of events related to tourism [40] or a completely different experience from those experienced in everyday life [41].

It is important for DMOs to comprehend the development and conveyance of successful experiences as they influence the tourists satisfaction, their ability to memorize the visit and the behavioural intention [42,43]. Therefore, they need to know the travellers' point of view, in order to build their experiential platforms using their recommendations and opinions [36]. An important literature field has become the measurement and evaluation of experiences $[37,40,44,45]$. The experience can be evaluated in its becoming only by observing the tourist in his natural habitat [46]. 
Therefore, it is difficult to investigate this directly and researchers are forced to interpret what the examinees express verbally, in writing, or through their behaviour. In order to understand the reality from the tourist's point of view rather than relying on artificial responses produced by traditional market research, researchers must look at them in the field, and ask for their impressions on the product/service at the time they consume it.

Destination Management Organisation (DMO), in order to protect and/or increase the attractiveness of the destination, needs to focus on experiences and analysis competitive dimension referring to maintain a high level of satisfaction of the needs of the tourist.

There is a relevant literature in order to measure and evaluate DMO performance [33,47-51]. However, many studies, although focusing on measurement system only refer to one experience case, one touristic service or one touristic destination at a time [43,44], using specific methodologies. Moreover, some researches evaluate experiences in a specific touristic field such as in the food [52], "dark" tourism [53], farm [54], casino [55], and shopping mall [56] contexts. The present study fills this gap by allowing to evaluate all the experiences of different nature spontaneously reported by visitors in a territory that is also very vast, which sees the presence of more tourist destinations. Therefore, this paper's main contribution consists in the proposal of a novel methodology capable to measure many tourist experiences in a large territory, with one or more destinations, and not only one experience case of one touristic destination. This circumstance makes it possible, for the DMO, to use this methodology in order to comprehend the experiential offer of a vast area and not only for the single touristic organisation to evaluate one single tourism experience. That seems particularly relevant as destinations more and more compete by emphasizing their experiential content [57].

The advanced methodology allows DMO to have useful information to analyse and measure the experiences offered by a territory in order to take decisions and actions capable of protecting and/or increase the credibility and interest of the same territory.

\section{Methodology}

This article advances a methodology of analysis and measurement of experiences based on reviews. The methodology is based on the following phases:

(a) investigation object: the experiences;

(b) destinations;

(c) platform of reviews; and

(d) analysis techniques.

(a) Definition of the investigation object: the experiences.

The object concerns the experiences, that is the "things to do" of a territory. Experience is important in choosing the tourist destination.

The traveller, in fact, is increasingly oriented to choose a tourist destination depending on what she/he can do during her/his trip.

The experiences can be aggregated in the following types:

- historical and cultural (visit to churches, castles, monuments, museum, etc.);

- outdoor and nature (beaches, lake/sea; mountain, parks, etc.);

- $\quad$ sport and well-being (sailing, golf, hiking, spas, thermal baths, etc.);

- $\quad$ shopping and crafts;

- food and wine (tastings, cooking classes, etc.); and

- $\quad$ services (characteristic or unusual transport, for example steam train, etc.).

(b) Destinations to be considered for analysis.

"Destination" was introduced in the tourism studies [58-63] to indicate the set of attractions and the physical place that encloses them. 
One or more touristic destinations can be distinguished in a vast territory depending on. The destinations of a territory include a set of attractions. It is important to define the destinations to have a measurement, at the aggregate level, of the experiences present in the same destination.

(c) Definition of the platform from which to collect the reviews.

The main traveller-generated content platform is TripAdvisor. TripAdvisor is an American travel website founded in February 2000. TripAdvisor has a "what to do" section, where travellers can review specific activities and experiences instead of tourism firms like hotels and restaurants.

This platform contains reviews on experiences able to cover the territory. In particular, the platform shows the main review portal "things to do" worldwide and it expands (in sixteen years) from a hotel review site to a "site of destinations". It is the eighth site in the world as the number of visits and the first in its sector, it is available in 28 languages and operates in 48 countries. Finally, it represents the largest community of travellers in the world, with 350 million visitors every month and more than 320 million reviews and opinions written by travellers around the world

The reason for this selection is due to its worldwide popularity [64]. Users create a personal profile, with reviews and ratings and share their experiences with others.

(d) Analysis techniques to be used.

Finally, the methodology is based on three different and integrated kind of techniques for analysing and measuring these experiences, according to reviews: (1) descriptive analysis; (2) sentiment analysis; and (3) Bayesian machine-learning-based content analysis.

\subsection{Descriptive Analysis}

This analysis focuses on the experiences that may be found online. It involves mapping the experiences genuinely reviewed by reviewers who spontaneously decide to post comments, without any kind of intermediation. The descriptions aim at providing state-of-the-art information in terms of:

- $\quad$ the name of the experience reviewed;

- the number of reviews per experience;

- the type of experience: historical and cultural; outdoor and nature; sport and well-being; shopping and crafts; food and wine; services.

- The type of reviewing visitors: families/couples/solo/business/friends;

- the year period for which the traveller has posted a review: Mar-May/July-Aug/Sept-Nov/ Dec-Feb; and

- the language used by the reviewer: Italian, English, German, Dutch, French, Russian, etc.

\subsection{Sentiment Analysis}

The study aims at analysing the experiences that may be observed online through sentiment analysis. In particular, the sentiment analysis technique aims to identify the attitude of a speaker or a writer with respect to a specific theme and the strength of such polarity. The attitude may concern the judgment or evaluation of the individual, the affective state (that is to say, the emotional state of the author when writing) or the expected emotional communication (that is, the emotional effect that the author wishes to exercise on the reader). In particular, our sentiment analysis focuses on the satisfaction rating entered for each experience directly by travellers. The TripAdvisor bubble rating is shown as a five-point Likert scale: $1=$ "Terrible", $2=$ "Poor", $3=$ "Average", $4=$ "Very Good" and $5=$ “Excellent" (TripAdvisor, 2015).

\subsection{Bayesian Machine-Learning-Based Content Analysis}

The semantic analysis of contents through Bayesian Machine-Learning-Based Content Analysis Methodology allows to process large amounts of data. Leximancer (a data mining software) employs 
two stages of information extraction—semantic (based on meaning) and relational (based on proximity and connection among topics).

Leximancer software (www.leximancer.com) is a tool for transforming lexical co-occurrence information from natural language into semantic patterns in an unsupervised manner. Leximancer is a text-mining or lexicographic tool that enables a visual analysis of texts. Leximancer uses a machine-learning technique to discover the main concepts in a text and to determine how they relate to each other [65]. In fact, Leximancer allows us to perform two types of content analysis: conceptual (thematic) and relational (semantic).

In the conceptual analysis, texts are analysed by the presence and frequency of the concepts contained in them; these concepts can be words, phrases, or more complex definitions, such as a set of words representing a concept. The software performs this analysis through its own pre-set dictionary. The relational analysis, however, measures how specific concepts relate to one another within the text. In this case, Leximancer measures the connections between the concepts identified in the text and extracts information representing them through conceptual maps. Themes that are physically closer together or overlapping on the map are closely linked in the text, and brighter circles on the map indicate the increased importance of that concept [66].

One of the advantages of Leximancer is its ability to handle large quantities of text, including the short and ungrammatical comments typically posted to a blog [67]. As analysis proceeds, the software automatically learns the words that predict certain concepts. The program generates word lists by assessing the contextual collocations of words through "term-occurrence information, such as co-occurrence, positions and frequencies of nouns and verbs" in the text $[68,69]$, suggesting clusters of meaning based on word groupings. Concepts that occur in very similar semantic contexts will form clusters [65].

Scholars have used Leximancer successfully across a number of disciplines in the social sciences $[67,70]$ and specifically in marketing $[66,71,72]$ where it has been especially used in order to analyse online communication.

\section{Results and Discussion}

The methodology referred to in the paragraph above applies to the Province of Brescia.

$\mathrm{DMO}$ can have information to analyse the online reviews on the experiences offered by the various destinations of the territory and implement actions able to protect and/or increase the credibility and interest of the same destinations and in general of the territory on which they insist.

$\mathrm{DMO}$ of Brescia destinations is Bresciatourism-Visit Brescia that promotes the territory and contribute to destinations' competitiveness and success.

The Province of Brescia is an Italian province located in Lombardia, with a population of 1,261,702 with Brescia as its main city. It is the second most populated province in Lombardia and the sixth in Italy. It covers the largest area in Lombardia, with a surface of $4784.36 \mathrm{sq}$. km., a population density of approximately 264 residents per sq. km., and 206 municipalities. The province of Brescia, the largest in the Lombardia region, boasts three main lakes-Garda Lake, Iseo Lake and Idro Lake, plus many other smaller mountain lakes, three valleys-Camonica valley, Trompia valley and Sabbia valley, plus other smaller valleys, as well as a large flat area south of the city, known as the "Pianura Bresciana", and various hilly areas that surround the city and extend east towards the Verona area, and west towards Franciacorta/Milan areas.

This section presents the methodological advanced in Section 3 and we discuss the results of the empirical application. The methodological steps are:

(a) the selection of the experiences to be considered for the analysis;

(b) the selection of the destinations to be considered for the analysis;

(c) the collection of data/reviews from the TripAdvisor platform; and

(d) the application of analysis techniques. 
(a) Experiences to be considered for the analysis.

The collected experiences, written spontaneously by reviewers without intermediaries of any kind, are: historical and cultural (churches, castles, monuments, museums, etc.); outdoor and nature (beaches, lake, paths, parks, etc.); sport and wellness (boat, golf, trekking SPA, etc.); shopping and crafts; food and wine; services (metro, lake navigation, etc.)

(b) Destinations to be considered for the analysis.

The destinations of the Province of Brescia are (Table 1):

- Brescia and Hinterland Brescia: cultural destination. The city of Brescia (with its 200,000 inhabitants) and the municipalities of its hinterland. The art city of the Mille Miglia (historic classic car race on the Brescia-Rome-Brescia route) and with the largest Roman archaeological area in North Italy, now Unesco site;

- "Pianura Bresciana" (Brescian Lowland): rural destination. The lowland is one of the most important agricultural areas of Italy;

- Iseo Lake: relaxing/leisure destination. Iseo Lake is a romantic lake, with Monte Isola in the downtown, the largest island in Italy;

- Franciacorta: wine destination. The land of the prestigious Franciacorta DOCG.

- Camonica valley: sport and cultural destination. The valley of skiing and rock engravings national parks, the first Unesco site in Italy;

- Trompia valley: sport and cultural destination. The valley of mines, iron, nature and art;

- Idro Lake and Sabbia valley: sport and relaxing destination. The land of outdoor sports and Idro Lake, the highest of the Lombardy pre-alpine lakes. Peace and relaxing on the border with Trentino;

- Garda Lake: holiday destination. The largest lake in Italy, between beaches and liberty villas.

(c) Collection of information/reviews from the TripAdvisor platform.

The experiences analysed involved the eight destinations in the province of Brescia. Considering the object of the survey (experiences), TripAdvisor was used as the information source. This choice was also driven by the need for a platform gathering 'conversations' able to cover the investigated territory in an equal and satisfactory way.

Table 1. The eight tourist destinations of the Province of Brescia.

\begin{tabular}{lc}
\hline \multicolumn{1}{c}{ No. Destinations } & No. Municipalities \\
\hline 1. Brescia City and Hinterland & 10 \\
2. Pianura Bresciana & 57 \\
3. Iseo Lake & 8 \\
4. Franciacorta & 19 \\
5. Camonica Valley & 41 \\
6. Trompia Valley & 18 \\
7. Sabbia Valley and Idro Lake & 27 \\
8. Garda Lake & 26 \\
Province of Brescia & 206 \\
\hline
\end{tabular}

(d) Application of analysis techniques.

The application included a first statistical analysis of the data collected, aimed at providing a descriptive analysis and a sentiment analysis of the number of reviews made available online as of 15 June, by travellers in the eight destinations analysed. Therefore, within this stage, the information collected for the descriptive analysis concerned: the name of the experiences of the Province of Brescia; the visibility of the experiences of the Province of Brescia (the number of overall reviews for the territorial areas, the type of reviews gathered: historical and cultural, outdoor and nature, sport and wellness, shopping and crafts, food and wine, services; the type of reviewer/traveller: families, couples, 
solo travellers, business, friends; the time of the year the traveller posted their review: Mar-May, Jun-Aug, Sept-Nov, Dec-Feb; the language used by the traveller in posting their review: Italian, English, German, Dutch, French, Russian, etc.

Secondly, we proceeded with the sentiment analysis aiming at detecting the satisfaction expressed by the traveller, that is to say, the rating given to each experience, according to the rating scale: excellent, very good, average, poor, and terrible.

Thirdly, the content analysis allowed the perception of the experience of the destinations by the travellers to be detected. The TripAdvisor reviews were grouped according to the ratings, in order to analyse and measure the main discussion topics and to bring out the relevant issues: positive (excellent, very good, average); and negative (poor, terrible).

Specifically, the analysis involved the content of the reviews collected from " 1 January 2014" to "15 June 2016", in Italian, English and German. The period covers a significant timeline, aiming at collecting recent and manageable contents in order to draw meaningful summaries on the perception of the experience of the eight destinations investigated.

The first pieces of evidence are illustrated below.

\subsection{Descriptive Analysis}

Table 2 shows 392 experiences reviewed by travellers with regard to destinations in the province of Brescia as of 15 June 2016, out of a total of 25,220 reviews observed. As regards to the geographical distribution of reviews, it should be noted that the greatest feedback comes from the Garda Lake area, with a percentage of $54.39 \%$ of reviews, while the lowest feedback comes from Trompia Valley destinations $(0.54 \%)$.

In general terms, the destinations with the greatest tourist potential—Garda Lake, Brescia City, Iseo Lake and Franciacorta area-have the highest number of reviews compared to other areas-Pianura Bresciana area and Camonica, Trompia, Sabbia Valleys.

Table 2. The number of experiences and reviews as of 15 June 2016.

\begin{tabular}{lcccc}
\hline \multirow{2}{*}{ Destinations } & \multirow{2}{*}{$\begin{array}{c}\text { No. } \\
\text { Municipalities }\end{array}$} & $\begin{array}{c}\text { No. } \\
\text { Experiences }\end{array}$ & \multicolumn{2}{c}{ No. Reviews at 15 June 2016 } \\
\cline { 5 - 5 } & & 60 & 4727 & No. \\
\hline 1. Brescia City and Hinterland & 10 & 32 & 1095 & 4.74 \\
2. Pianura Bresciana & 57 & 38 & 1955 & 7.75 \\
3. Iseo Lake & 8 & 52 & 1860 & 7.38 \\
4. Franciacorta & 19 & 57 & 1669 & 6.62 \\
5. Camonica Valley & 41 & 11 & 133 & 0.53 \\
6. Trompia Valley & 18 & 12 & 307 & 1.22 \\
7. Sabbia Valley and Idro Lake & 27 & 130 & 13,474 & 53.43 \\
8. Garda Lake & 26 & 392 & 25,220 & 100.00 \\
Total & 206 & &
\end{tabular}

The mapping of the 392 reviews of the Province of Brescia showed that the main types of experiences reviewed are: the historical/cultural ones, those focusing on landscape and nature, sport and leisure (Table 3).

Table 3. Type of experience and number of reviews as of 15 June 2016.

\begin{tabular}{lcccc}
\hline \multirow{2}{*}{ Type of Experience } & \multicolumn{2}{c}{ Experiences } & \multicolumn{2}{c}{ Reviews } \\
\cline { 2 - 5 } & No. & $\%$ & No. & $\%$ \\
\hline Historical and cultural & 192 & 48.98 & 14,144 & 56.08 \\
Outdoor and nature & 58 & 14.80 & 3742 & 14.84 \\
Sport and well-being & 81 & 20.66 & 5197 & 20.61 \\
Shopping and crafts & 12 & 3.06 & 886 & 3.51 \\
Food and wine & 42 & 10.71 & 938 & 3.72 \\
Services & 7 & 1.79 & 313 & 1.24 \\
Total & 392 & 100.00 & 25,220 & 100.00 \\
\hline
\end{tabular}


Furthermore, the observation of the reviews may contribute to the definition of a ranking of the most reviewed experiences. Table 4 shows the top ten for the whole Brescia area, which represent $44 \%$ of the total number of reviews $(11,185$ out of 25,220$)$.

Table 4. The main reviews of the eight destinations.

\begin{tabular}{lc}
\hline \multicolumn{1}{c}{ Experiences } & No. Reviews of Experiences/Total Reviews \\
\hline 1. Thermal Baths of Sirmione-SPA-Termale Aquaria & 7.74 \\
2. Scaligera Fortress and Castle & 7.41 \\
3. Catullo Cavern & 7.19 \\
4. Vittoriale degli Italiani & 6.83 \\
5. Brescia Castle & 3.22 \\
6. Lake of Iseo & 2.99 \\
7. Old cathedral of Brescia & 2.70 \\
8. S. Giulia Museum & 2.44 \\
9. Thermal Baths of Boario & 1.92 \\
10. Outlet Village Franciacorta & 1.92 \\
\hline
\end{tabular}

\subsection{Sentiment Analysis}

The analysis allows measuring the opinion expressed by the reviewers according to the satisfaction rating of the reviews for the Province of Brescia (Table 5) 53.92\% of the reviewers gave an 'excellent' rating, $33.81 \%$ a 'very good' and $8.38 \%$ an 'average' rating.

Table 5. Percentage of reviewer satisfaction for the Province of Brescia.

\begin{tabular}{lcccccc}
\hline \multicolumn{1}{c}{ No. Destinations } & $\begin{array}{c}\text { Excellent } \\
\mathbf{( \% )}\end{array}$ & $\begin{array}{c}\text { Very Good } \\
\mathbf{( \% )}\end{array}$ & $\begin{array}{c}\text { Average } \\
\mathbf{( \% )}\end{array}$ & $\begin{array}{c}\text { Poor } \\
\mathbf{( \% )}\end{array}$ & $\begin{array}{c}\text { Terrible } \\
\mathbf{( \% )}\end{array}$ & $\begin{array}{c}\text { No. } \\
\text { Reviews }\end{array}$ \\
\hline 1. Brescia City and Hinterland & 59.61 & 31.14 & 6.94 & 1.48 & 0.83 & 4727 \\
2. Po Valley & 52.43 & 35.17 & 7.46 & 2.33 & 2.61 & 1072 \\
3. Iseo Lake & 46.83 & 38.88 & 10.43 & 2.24 & 1.61 & 1610 \\
4. Franciacorta & 42.74 & 37.99 & 12.35 & 3.91 & 3.02 & 1790 \\
5. Camonica Valley & 53.61 & 34.42 & 7.88 & 2.71 & 1.38 & 1662 \\
6. Trompia Valley & 62.41 & 32.33 & 3.01 & 1.50 & 0.75 & 133 \\
7. Sabbia Valley and Idro Lake & 55.37 & 31.92 & 7.82 & 1.63 & 3.26 & 307 \\
8. Garda Lake & 54.30 & 33.46 & 8.30 & 2.06 & 1.88 & 13,474 \\
\hline
\end{tabular}

On the other hand, the percentages of 'poor' and 'terrible' ratings total respectively $2.14 \%$ and $1.75 \%$. Therefore, the positive rating (excellent, very good and average) represents $96.11 \%$ and the negative rating represents $3.89 \%$. The analysis allows comparing the reviewers' level of satisfaction for different tourist destinations within the same area, thus contributing to the definition of possible interventions, aimed at providing uniform quality standards.

\subsection{Bayesian Machine Learning-Based Content Analysis}

The perception of experiential offering can be detected starting from the analysis of the contents of the reviews posted by travellers, for the period from " 1 December 2014" to "15 June 2016", and based on a total of 17,720 reviews, which corresponds to $70.26 \%$ of the reviews collected over the entire period investigated. This number of reviews is significant enough (for a limited period of time) to allow to develop an effective content analysis. However, due to the limited number of reviews for some destinations, such as Trompia valley and Sabbia valley, some phases of the analysis could not deliver reliable results. Below is a summary of the results of the semantic analysis, conducted using the Leximancer tool, grouped according to the reviewer's rating (positive and negative) and language (Italian, English, and German). By way of example, some results of a single destination (Brescia and its hinterland) are shown in Italian (Figure 1) and English (Figure 2), positive ratings (excellent, very good, average). 


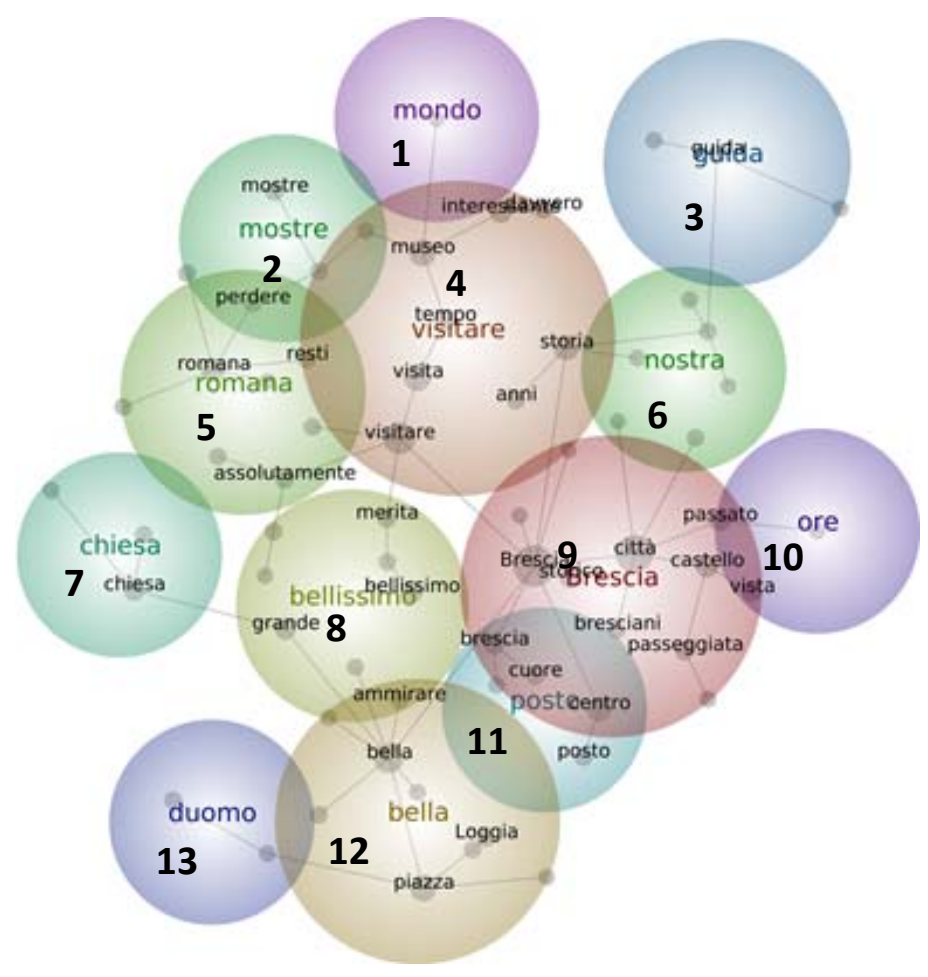

Figure 1. Concept map 'The city of Brescia and its hinterland'-reviews in Italian-positive ratings. 1. World; 2. Exhibitions, to lose; 3. Guide; 4 . Visit, interest, museum, time, history, visit, years; 5 . Ancient Roman Art, absolutely; 6. Our; 7. Church; 8. Beautiful, attention, great; 9. Brescia, city, past, castle, panoramic, walk; 10. Hours; 11 Heart, Downtown, place; 12. Beautiful, enjoy, "Loggia", square; and 13. Cathedral.

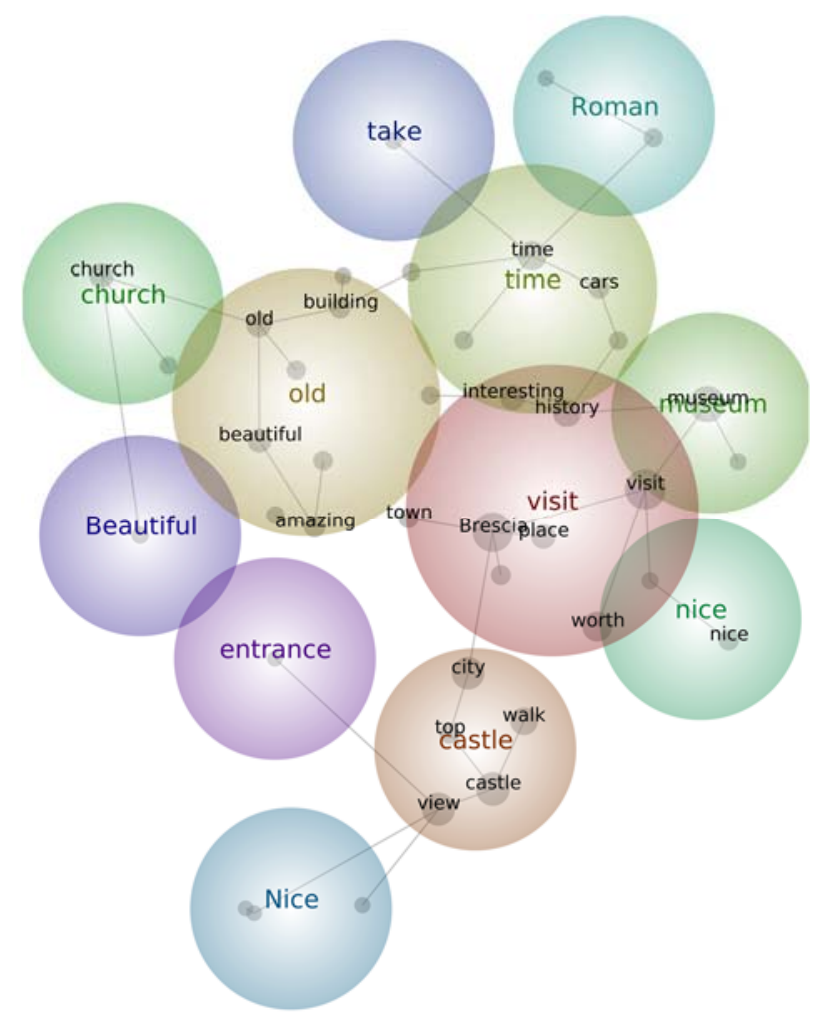

Figure 2. Concept map 'The city of Brescia and its hinterland'—reviews in English—positive ratings. 
The main topic is Brescia, followed by the term 'to visit' (Figure 1). The words related to the topic Brescia are: city, downtown, historical, castle, past, walk, visit, Brescia-related elements (in Italian: bresciani). The city is, therefore, considered by the Italian reviewers as a catalyst and a container of cultural elements. The city of Brescia features some elements such as the Cathedral, the Loggia square and the Santa Giulia museum that appear to be 'driven' by the visibility of the city.

This content analysis highlights the absence of the word "castle", whereas the castle location totalled the highest number of reviews (mainly foreign travellers; see Figure 2). In addition, Italian reviewers, unlike foreign tourists, do not consider the Brescia Castle as a separate feature. The most relevant topics are sightseeing and the city.

The elements of dissatisfaction concern a very limited number of reviews and refer to a few organisational aspects of the visit (opening hours, information, etc.).

The initial descriptive analysis allows providing the first observations as regards to the elements a Destination Management Organisation (DMO) can leverage to improve its destination with a view to attractiveness. First of all, it is possible to understand which types of experiences are offered in the area. In our application, the territory, as a whole, offers experiences that fall into all types covered herein (historical-cultural, landscapes/nature, sports and wellness, shopping and craftsmanship, food and wine, services). As resulting from the observations, than, the number of reviews is already an important parameter to be looked into by decision-makers, as regards to the communication of the experiences of a destination. At the same time, the presence of many little-known experiences (shopping/crafts, food and wine, sports, etc.) or experiences that do not generate 'memories' for the traveller, should be considered.

Implementing the sentiment analysis, it is possible to register the customer satisfaction related to the considered experiences. In our case, the experiences are positively assessed. Some differences result in between different touristic areas, different type of experiences and different nationalities. It is also possible to notice if there is a positive or negative trend in customer satisfaction.

The content analysis, helps to deepen the knowledge of the customer satisfaction determinants and the experience components. For example, in our application it can be said that the negative reviews do not concern the value of experiences, but they, usually, concern recoverable gaps, i.e., organisational shortcomings and lack of information. The relevance evaluation of the experience characteristics and the internal connections monitoring allow to understand the impact that these experiences have on the tourists perception, memories and willingness to spread these information, In our application, valuable information have showed up on the presence/absence of the experience brand, the different evaluation of Italians and foreigners, the importance of historical versus environmental aspects, the higher or lower integration of the experience with the local territory, and so on.

\section{Conclusions and Implications}

In this data-driven age, DMOs can go forward and overcome competitors by integrating analysis methodologies into their business strategies [73]. However, the viability of the methodology used to analyse big data is essential for the DMO. The methodology used to analyse and measure the experiences of a territory composed of many touristic destinations allows the DMO to use information taken from user generated content so that it can detect strengths and weaknesses and be able to activate all corrective actions to make its destination more attractive, thanks to the quality of the experiences conveyed. Moreover, tourist opinions, as well as residents opinions are relevant for a destination [74], and this methodology gives the possibility to detect both.

As the traveller is increasingly orientated to choose a tourist destination in function of what he can do during his stay, the DMO can also check if the territory offers relevant experiences that fall within the local culture or resources (historical-cultural, landscapes, nature, sports, and wellness, shopping and crafts, food and wine, services) and if some are not well perceived by the tourists. More and more the traveller chooses a trip or excursion based on the authenticity of the experiences that the destinations express and the ability to "do things" that meet their own interests and expectations $[31,75,76]$. 
The travellers want to immerse themselves in the destinations that value the culture and locality of local territories, exalting practices and knowledge, discovering traditions, arts and crafts. They want to become the protagonist of the places they choose, not just to visit them, but to live them, to share them, to identify themselves, to breathe their emotions, as if they were part of that place, of those traditions, of those people. Tourist experiences give a positive stimulation, leave traces in memory $[77,78]$, and lead to overall satisfaction $[42,45]$. Moreover, they must be understood as highly subjective and variable.

Measuring the results allows the DMO to evaluate the adequacy of the experience with respect to the specific need, desire, and satisfaction of the traveller. In particular, it would allow a realignment of the objectives to be pursued in line with the effective competitive success of a destination and the companies operating there.

The proposed methodology, furthermore, allows the DMO to process longitudinal studies and to evaluate destination strategies adopted, but always in a long time perspective. Indeed, it takes time to the tourists to express a real reaction to a change in the local proposed experiences, as this is not a methodology based on a survey but on a voluntary peer to peer communication.

Author Contributions: This article is a joint work of the two authors. M.B. contributed to the literature review. She participated in the methodology/results and discussion (phases: c, d/Bayesian Machine-Learning-Based Content Analysis) and to write the paper. S.F. participated in the methodology/results and discussion (phases: $a, b, d /$ Descriptive Analysis and Sentiment Analysis) and to write the paper. All authors participated in the introduction and gave thought to the conclusions.

Funding: This research was funded by Bresciatourism-Visit Brescia (DMO of Brescia destinations, Italy).

Conflicts of Interest: The authors declare no conflict of interest.

\section{References}

1. Sparks, B.A.; Perkins, H.E.; Buckley, R. Online travel reviews as persuasive communication: The effects of content type, source, and certification logos on consumer behavior. Tour. Manag. 2013, 39, 1-9. [CrossRef]

2. Xiang, Z.; Gretzel, U. Role of social media in online travel information search. Tour. Manag. 2010, 31, $179-188$. [CrossRef]

3. Parent, M.; Plangger, K.; Bal, A. The new WTP: Willingness to participate. Bus. Horiz. 2011, 54, $219-229$. [CrossRef]

4. Kim, J.; Fesenmaier, D.R. Sharing tourism experiences: The posttrip experience. J. Travel Res. 2017, 56, 28-40. [CrossRef]

5. Travel Trends \& Motiv, Global Findings. TripBarometer Report. 2016. Available online: www.tripadvisor.com/TripAdvisorInsights/wp-content/uploads/2018/01/TripBarometer-2016-TravelerTrends-Motivations-Global-Findings.pdf (accessed on 20 May 2018).

6. Fuggle, L. The Travel and Tourism Statistics and Insights to Know about in 2016. Travel Trend Report. 2016. Available online: www.trekksoft.com (accessed on 15 January 2019).

7. Mauri, A.G.; Minazzi, R. Web reviews influence on expectations and purchasing intentions of hotel potential customers. Int. J. Hosp. Manag. 2013, 34, 99-107. [CrossRef]

8. King, R.A.; Racherla, P.; Bush, V.D. What we know and don't know about online word-of-mouth: A review and synthesis of the literature. J. Interact. Mark. 2014, 28, 167-183. [CrossRef]

9. Negroponte, N.; Maes, P. Electronic word of mouth. Wired Magazine 1996, 4, 1-2. Available online: http:/ /archive.wired.com/wired/archive/4.10/negroponte.html (accessed on 10 October 2017).

10. Bilgihan, A.; Barreda, A.; Okumus, F.; Nusair, K. Consumer perception of knowledge-sharing in travel-related online social networks. Tour. Manag. 2016, 52, 287-296. [CrossRef]

11. Baka, V. The becoming of user generated reviews: Looking at the past to understand the future of managing reputation in the travel sector. Tour. Manag. 2016, 53, 148-162. [CrossRef]

12. Choe, Y.; Kim, J.; Fesenmaier, D.R. Use of social media across the trip experience: An application of latent transition analysis. J. Travel Tour. Mark. 2017, 34, 431-443. [CrossRef]

13. Vermeulen, I.E.; Seegers, D. Tried and tested. The impact of online hotel reviews on consumer consideration. Tour. Manag. 2009, 30, 123-127. [CrossRef] 
14. Park, D.H.; Lee, J.; Han, I. The effect of on-line consumer reviews on consumer purchasing intention: The moderating role of involvement. Int. J. Electron. Comput. 2007, 11, 125-148. [CrossRef]

15. Munar, A.M.; Jacobsen, J.K.S. Motivations for sharing tourism experiences through social media. Tour. Manag. 2014, 43, 46-54. [CrossRef]

16. Zhang, H.; Wu, Y.; Buhalis, D. A model of perceived image, memorable tourism experiences and revisit intention. J. Destin. Mark. Manag. 2017, 8, 326-336. [CrossRef]

17. Forgas-Coll, S.; Palau-Saumell, R.; Matute, J.; Tárrega, S. How Do Service Quality, Experiences and Enduring Involvement Influence Tourists' Behavior? An Empirical Study in the Picasso and Miró Museums in Barcelona. Int. J. Tour. Res. 2017, 19, 246-256. [CrossRef]

18. Mariani, M.M.; Di Felice, M.; Mura, M. Facebook as a destination marketing tool: Evidence from Italian regional Destination Management Organizations. Tour. Manag. 2016, 54, 321-343. [CrossRef]

19. Jalilvand, M.R.; Samiei, N. Examining the structural relationships of electronic word of mouth, destination image, tourist attitude toward destination and travel intention: An integrated approach. J. Destin. Mark. Manag. 2012, 1, 134-143. [CrossRef]

20. Voss, C. Trends in the Experience and Service Economy: The Experience Profit Cycle; London School of Economics: London, UK, 2004.

21. Quan, S.; Wang, N. Towards a structural model of the tourist experience: An illustration from food experiences in tourism. Tour. Manag. 2004, 25, 297-305. [CrossRef]

22. Pizam, A. Creating memorable experiences. Int. J. Hosp. Manag. 2010, 3, 343. [CrossRef]

23. Tse, P.; Crotts, J.C. Antecedents of novelty seeking: International visitors' propensity to experiment across Hong Kong's culinary traditions. Tour. Manag. 2005, 26, 965-968. [CrossRef]

24. Ritchie, B.; Crouch, G. The competitiveness destination: A sustainability perspective. Tour. Manag. 2000, 21, $1-7$.

25. D'Harteserre, A. Lessons in Managerial Destination Competitiveness in the case of Foxwoods Casiro Resort. Tour. Manag. 2000, 21, 20-38.

26. Crouch, G.I. Modeling Destination Competitiveness: A Survey and Analysis of the Impact of Competitiveness; Cooperative Research Centre for Sustainable Tourism: Gold Coast, OLD, Australia, 2007.

27. Franzoni, S. Measuring the sustainability performance of the tourism sector. Tour. Manag. Perspect. 2015, 16, 22-27. [CrossRef]

28. Neuhofer, B.; Buhalis, D.; Ladkin, A. Conceptualising technology enhanced destination experiences. J. Destin. Mark. Manag. 2012, 1, 36-46. [CrossRef]

29. Neuhofer, B.; Buhalis, D.; Ladkin, A. Smart technologies for personalized experiences: A case study in the hospitturnality domain. Electron. Mark. 2015, 25, 243-254. [CrossRef]

30. Knutson, B.; Beck, J.; Him, S.; Cha, J. Identifying the Dimensions of the Experience Construct. J. Hosp. Leisure Mark. 2006, 15, 31-47. [CrossRef]

31. Stamboulis, Y.; Skayannis, P. Innovation strategies and technology for experience-based tourism. Tour. Manag. 2003, 24, 35-43. [CrossRef]

32. Cetin, G.; Bilgihan, A. Components of cultural tourists' experiences in destinations. Curr. Issues Tour. 2016, 19, 137-154. [CrossRef]

33. Dwyer, L.; Kim, C. Destination competitiveness: Determinants and indicators. Curr. Issues Tour. 2003, 6, 369-414. [CrossRef]

34. Holbrook, M.B.; Hirschman, E.C. The experiential aspects of consumption: Consumer fantasies, feelings, and fun. J. Consum. Res. 1982, 9, 132-140. [CrossRef]

35. Pine, J.; Gilmore, J. Welcome to the Experience Economy. Harv. Bus. Rev. 1998, 76, 97-105. [PubMed]

36. Schmitt, B. Experiential Marketing: How to Get Customers to Sense, Feel, Think, Act, and Relate to Your Company and Brands; Free Press: New York, NY, USA, 1999.

37. Oh, H.; Fiore, A.M.; Jeoung, M. Measuring experience economy concepts: Tourism applications. J. Travel Res. 2007, 46, 119-132. [CrossRef]

38. Otto, J.E.; Ritchie, J. The Service Experience in Tourism. Tour. Manag. 1996, 17, 165-174. [CrossRef]

39. Gupta, S.; Vajic, M. The Contextual and Dialectical Nature of Experiences; Fitzsimmons, J.A., Fitzsimmons, M.J., Eds.; New Service Development: Creating Memorable Experiences; Sage: Thousand Oaks, CA, USA, 2000.

40. Tung, V.W.S.; Ritchie, J.B. Exploring the essence of memorable tourism experiences. Ann. Tour. Res. 2011, 38, 1367-1386. [CrossRef] 
41. MacCannell, D. Staged authenticity: Arrangements of Social Space in Tourist Settings. Am. J. Soc. 1973, 79, 589-603. [CrossRef]

42. Ali, F.; Ryu, K.; Hussain, K. Influence of experiences on memories, satisfaction andbehavioral intentions: A study of creative tourism. J. Travel Tour. Mark. 2016, 33, 85-100. [CrossRef]

43. Barnes, S.J.; Mattsson, J.; Sørensen, F. Remembered experiences and revisit intentions: A longitudinal study of safari park visitors. Tour. Manag. 2016, 57, 286-294. [CrossRef]

44. Kim, J.H.; Ritchie, J.B.; McCormick, B. Development of a scale to measure memorable tourism experiences. J. Travel Res. 2012, 51, 12-25. [CrossRef]

45. Bigné, J.E.; Andreu, L.; Gnoth, J. The theme parkexperience: An analysis of pleasure, arousal and satisfaction. Tour. Manag. 2005, 26, 833-843. [CrossRef]

46. Bonera, M.; Corvi, E.; Codini, A.P.; Ma, R. Does Nationality Matter in Eco-Behaviour? Sustainability 2017, 9 , 19-35. [CrossRef]

47. Manning, T. Indicators of tourism sustainability. Tour. Manag. 1999, 20, 179-181.

48. Vera, J.F.; Ivars, J.A. Measuring sustainability in a mass tourist destination: Pressures, perceptions and policy responses in Torrevieja, Spain. J. Sustain. Tourism 2003, 11, 181-203. [CrossRef]

49. White, V.; McCrum, G.; Blackstock, K.L.; Scott, A. Indicators and Sustainable Tourism: Literature Review; Macaulay Institute: Aberdeen, UK, 2006.

50. Miller, G. The development of indicators for sustainable tourism: Results of a Delphi survey of tourism researchers. Tour. Manag. 2001, 22, 351-362. [CrossRef]

51. Choi, H.S.C.; Sirakaya, E. Sustainability indicators for managing community tourism. Tour. Manag. 2006, 27, 1274-1289. [CrossRef]

52. Laing, J.; Wheeler, F.; Reeves, K.; Frost, W. Assessing the experiential value of heritage assets: A case study of a Chinese heritage precinct, bendigo, Australia. Tour. Manag. 2014, 40, 180-192. [CrossRef]

53. Yan, B.J.; Zhang, J.; Zhang, H.L.; Lu, S.J.; Guo, Y.R. Investigating the motivationeexperience relationship in a dark tourism space: A case study of the beichuan earthquake relics, China. Tour. Manag. 2016, 53, 108-121. [CrossRef]

54. Capriello, A.; Mason, P.R.; Davis, B.; Crotts, J.C. Farm tourism experiences in travel reviews: A cross-comparison of three alternative methods for data analysis. J. Bus. Res. 2013, 66, 778-785. [CrossRef]

55. Wong, I.A.; Wu, J.S. Understanding casino experiential attributes: An application to market positioning. Int. J. Hosp. Manag. 2013, 35, 214-224. [CrossRef]

56. Shim, C.; Santos, C.A. Tourism, place and placelessness in the phenomenological experience of shopping malls in Seoul. Tour. Manag. 2014, 45, 106-114. [CrossRef]

57. Buhalis, D. Marketing the competitive destination of the future. Tour. Manag. 2000, 21, 97-116. [CrossRef]

58. Leiper, N. Tourist attraction systems. Ann. Tour. Res. 1990, 17, 367-384. [CrossRef]

59. Mathieson, A.; Wall, G. Tourism: Economic, Physical and Social Impacts; Longman Scientific \& Technica: New York, NY, USA, 1992.

60. Pearce, D. Tourism and the Autonomous Communties in Spain. Ann. Tour. Res. 1997, 24, 156-177. [CrossRef]

61. Kotler, P.; Haider, D.; Rein, I. Marketing Places; Free Press: New York, NY, USA, 1993.

62. Kozak, M. Destination benchmarking. Ann. Tour. Res. 2002, 29, 497-520. [CrossRef]

63. Kerr, B.; Barrong, G.; Wood, R.C. Politics, policy and regional tourism administration: A case examination of Scottish area tourist board funding. Tour. Manag. 2011, 22, 649-657. [CrossRef]

64. Ayeh, J.K.; Au, N.; Law, R. Do we believe in TripAdvisor? examining credibility perceptions and online travelers' attitude toward using user generated content. J. Travel Res. 2013, 52, 437-452. [CrossRef]

65. Rooney, D. Knowledge, economy, technology and society: The politics of discourse. Telemat. Inf. 2005, 22, 405-422. [CrossRef]

66. Robson, K.; Farshid, M.; Bredican, J.; Humphrey, S. Making sense of online consumer reviews: A methodology. Int. J. Mark. Res. 2013, 55, 521-537. [CrossRef]

67. Smith, A.E.; Humphreys, M.S. Evaluation of unsupervised semantic mapping of natural language with Leximancer concept mapping. Behav. Res. Met. 2006, 38, 262-279. [CrossRef]

68. Kamimaeda, N.; Izumi, N.; Hasida, K. Evaluation of participants' contributions in knowledge creation based on semantic authoring. Learn. Org. 2007, 14, 263-280. [CrossRef]

69. Young, L.; Denize, S. Competing interests: The challenge to collaboration in the public sector. Int. J. Sociol. Soc. Pol. 2008, 28, 46-58. [CrossRef] 
70. Scott, N.; Smith, A.E. Use of Automated Content Analysis Techniques for Event Image Assessment. Tour. Recreat. Res. 2005, 30, 87-91. [CrossRef]

71. Campbell, C.; Pitt, L.F.; Parent, M.; Berthon, P.R. Understanding consumer conversations around ads in a Web 2.0 world. J. Advert. 2011, 40, 87-102. [CrossRef]

72. Campbell, C.; Pitt, L.F.; Parent, M.; Berthon, P. Tracking back-talk in consumer-generated advertising: An analysis of two interpretative approaches. J. Advert. Res. 2011, 51, 224-238. [CrossRef]

73. Jimenez-Marquez, J.L.; Gonzalez-Carrasco, I.; Lopez-Cuadrado, J.L.; Ruiz-Mezcua, B. Towards a big data framework for analyzing social media content. Int. J. Inf. Manag. 2019, 44, 1-12. [CrossRef]

74. Cassia, F.; Vigolo, V.; Ugolini, M.M.; Baratta, R. Exploring city image: residents' versus tourists' perceptions. TQM J. 2018, 30, 476-489. [CrossRef]

75. Ellis, G.D.; Rossman, J.R. Creating value for participants through experience staging: Parks, recreation, and tourism in the experience industry. J. Park Recreat. Admin. 2008, 26, 1-20.

76. Zehrer, A. Service experience and service design: Concepts and application in tourism SMEs. Manag. Serv. Qual. 2009, 19, 332-349. [CrossRef]

77. Morgan, M.; Xu, F. Student travel experiences: Memories and dreams. J. Hosp. Mark. Manag. 2009, 18, 216-236. [CrossRef]

78. Martin, D. Uncovering unconscious memories and myths for understanding international tourism behavior. J. Bus. Res. 2010, 63, 372-383. [CrossRef]

(C) 2019 by the authors. Licensee MDPI, Basel, Switzerland. This article is an open access article distributed under the terms and conditions of the Creative Commons Attribution (CC BY) license (http:/ / creativecommons.org/licenses/by/4.0/). 